\title{
Perspective
}

\section{Antioxidants, Food Processing and Health}

\author{
Borut Poljsak $^{1}$, Vito Kovač ${ }^{1}(\mathbb{D})$ and Irina Milisav ${ }^{1,2, * \mathbb{D}}$ \\ 1 Laboratory of Oxidative Stress Research, Faculty of Health Sciences, University of Ljubljana, \\ Zdravstvena pot 5, SI-1000 Ljubljana, Slovenia; borut.poljsak@zf.uni-lj.si (B.P.); vito.kovac@gmail.com (V.K.) \\ 2 Faculty of Medicine, Institute of Pathophysiology, University of Ljubljana, \\ Zaloska 4, SI-1000 Ljubljana, Slovenia \\ * Correspondence: irina.milisav@mf.uni-lj.si; Tel.: +386-1-543-7022; Fax: +386-1-543-7021
}

Citation: Poljsak, B.; Kovač, V.; Milisav, I. Antioxidants, Food Processing and Health. Antioxidants 2021, 10, 433. https://doi.org/ 10.3390/antiox10030433

Academic Editors: Monica Rosa Loizzo and Rosa Tundis

Received: 15 February 2021

Accepted: 8 March 2021

Published: 11 March 2021

Publisher's Note: MDPI stays neutral with regard to jurisdictional claims in published maps and institutional affiliations.

Copyright: (c) 2021 by the authors. Licensee MDPI, Basel, Switzerland. This article is an open access article distributed under the terms and conditions of the Creative Commons Attribution (CC BY) license (https:/ / creativecommons.org/licenses/by/ $4.0 /)$.

\begin{abstract}
The loss and/or modification of natural antioxidants during various food processing techniques and storage methods, like heat/thermal, UV, pulsed electric field treatment, drying, blanching and irradiation is well described. Antioxidants in their reduced form are modified mainly by oxidation, and less by pyrolysis and hydrolysis. Thus, they are chemically converted from the reduced to an oxidized form. Here we describe the neglected role of the oxidized forms of antioxidants produced during food processing and their effect on health. While natural antioxidants in their reduced forms have many well studied health-promoting characteristics, much less is known about the effects of their oxidized forms and other metabolites, which may have some health benefits as well. The oxidized forms of natural antioxidants affect cell signaling, the regulation of transcription factor activities and other determinants of gene expression. Very low doses may trigger hormesis, resulting in specific health benefits by the activation of damage repair processes and antioxidative defense systems. Functional studies determining the antioxidants' effects on the organisms are important, especially as reduced or oxidized antioxidants and their metabolites may have additional or synergistic effects.
\end{abstract}

Keywords: antioxidants; polyphenols; food processing; health; oxidation; hormesis; stress response

\section{Introduction}

The oxidation of food, resulting in rancidity, is the second most important cause of food impairment. The first cause is microbial spoilage [1]. The naturally occurring antioxidants in fruits and vegetables scavenge harmful free radicals, and thus have a protective effect against oxidation, improve the nutritional value and prevent food spoilage. Besides, the ingestion of antioxidants prevents intracellular oxidation, which has been associated with health promotion and the prevention of most degenerative diseases [2]. The health-protective properties of fruits, vegetables, culinary herbs and spices also result from the presence of low-molecular antioxidants that protect the cells and their structures against oxidative stress and oxidative damage [3]. Namely, oxidative stress is involved, as a cause or consequence, in over 100 human diseases [4]. A positive correlation between the consumption of whole fruits and vegetables and the prevention of diseases, like atherosclerosis, cancer, diabetes, arthritis, an improved cardiovascular and neurological health, reduced cancer incidence, increased longevity and lowered overall mortality was observed in humans [5-9]. It is unknown if an individual antioxidant or the synergy of several different antioxidants (some of them perhaps undiscovered) in fruits and vegetables contributes to disease prevention. The observed beneficial effects on health might also originate from other phytochemicals present in food, like dietary fiber, folate, vitamins, polyphenols and potassium [10]. The intake of foods that are naturally rich in antioxidants (a daily intake of at least $400 \mathrm{~g}$ of fruit and vegetables) has been recommended to the general public by the World Health Organization as a way to protect oneself against chronic diseases [11]; however, there is no formal recommendation for the type, number or amount of antioxidants that should be consumed daily [12]. 
The enrichment of food with synthetic antioxidants during food processing and preservation is an established method. However, it uses mostly synthetic additives that are not well accepted by modern consumers, who prefer the consumption of natural antioxidants (e.g., tocopherols, carotenoids and ascorbic acid or extracts from rosemary, sage, thyme, savory, marjoram, nutmeg and ginger) and food free of synthetic additives [13].

An alternative to adding synthetic antioxidants (e.g., butylated hydroxyanisole (BHA), butylated hydroxytoluene (BHT), propyl gallate (PG) and tert-butyl hydroquinone (TBHQ)) to foods is to use herbs and spices. Indeed, culinary herbs and spices are a rich source of phytochemicals $[14,15]$ and an antioxidant-dense dietary source $[16,17]$ resulting in a broad spectrum of health promotion activities $[17,18]$. Herbs, such as dill, garden thyme, rosemary, peppermint, paprika, garlic, curry, chili and black pepper have a high antioxidant activity, some even exceeding the antioxidant activity found in fruits and vegetables $[19,20]$.

Due to their strong antioxidant activity, spices and herbs can inhibit or delay lipid oxidation and thus improve sensorial acceptability and prolong the shelf life of foods [21-24]. Antioxidants from herbs and spices form complexes with metal ions (Fenton reaction) and/or quench free radicals that are formed during the initiation phase of autoxidation. [21]. A rancid taste and aroma as a result of the lipid oxidation of foods trigger oxidative degradation, leading to a deterioration of food quality and causing undesirable tastes and odors in foods and changes in color and texture [25]. By inhibiting or delaying the onset of lipid oxidation and the development of rancidity in processed foods that undergo various processes during production, natural antioxidants from spices and herbs provide efficient antioxidant protection to minimize the oxidative deterioration of foods [16].

As many studies revealed the decreased availability of health-promoting compounds such as phytochemicals and antioxidants during improper food processing, handling and long-term storage [26], and due to the increased consumer perception, interest and awareness, the food industry currently faces the challenge of whether and which food processing techniques and storage methods should be used to minimize the impact on food quality.

\section{Processing Techniques That Affect Antioxidant Content and the Oxidative Stability of Food}

Many food preservation technologies are used to retain the nutritional attributes of fresh foods and to enhance organoleptic qualities, shelf-life and food safety. Different types of food-processing operations affect the antioxidants and oxidative stability of foods, resulting mostly in losses of antioxidant activity, which occur rapidly during heating or slowly during the storage process [13]. Fruits and vegetables are often subjected to various kinds of processing methods to inactivate microorganisms and to extend shelf life and sensory properties. Such treatment techniques include elevated temperature treatment (pasteurization, sterilization, blanching, evaporation, drying, roasting, frying, microwave heating, infrared heating, ohmic heating), ambient temperature treatment (fermentation, curing, smoking), freezing, high hydrostatic pressure, pulsed electric field, drying/dehydration and food ionizing (gamma and electron beam) and non-ionizing UV-radiation [27]. Each preservation method applied influences the antioxidant content, bioavailability and activity of micronutrients present in fruits and vegetables (Table 1).

For example, thermal processing and long-term storage were shown to reduce the antioxidant activity of fruits [28]. Different cooking methods lowered the antioxidant content of food [29,30]. Long-term frozen storage (12 months) significantly decreased vitamin $C$ and the free radical scavenging capacity, for example in raspberry fruit [31]. Dehydration techniques also affected the phytochemical contents and reduced antioxidant activities, e.g., in berries [32]. Processing methods (soaking and roasting) influenced the total phenolic, flavonoid and antioxidant contents in selected dry beans [33]. High-pressure processing of fruit smoothies significantly affected the antioxidant activity [28] and up to $45 \%$ antioxidant capacity was lost after processing fruits into jams [34]. 
Moreover, the antioxidant activity of black pepper, allspice and oregano was reduced after the treatment at $130^{\circ} \mathrm{C}$ for $5 \mathrm{~min}$, with the exception of the increased content of phenolic substances in black pepper [35].

Auto-oxidation and loss of total antioxidant content occur in different fruits and vegetables during food processing and storage. Paradoxically, however, storage or food processing can sometimes improve the antioxidant activity, increase the bio-availability of natural antioxidants, increase their radical scavenging activity [36] and result in the de novo formation of substances with antioxidant properties [37]. For example, some cooking methods can improve the antioxidant capacity of selected vegetables [38-41]. Cooking (boiling, steaming, microwaving), for example, increased the total phenolic content and antioxidant properties in a pumpkin pulp [42]. The processing techniques, such as microwaving, boiling and roasting, resulted in a 2- to 3-fold increase of the red beet's antioxidant activity, as compared to the control [43]. Thermal processing increased the total antioxidant activity of tomato and sweet corn $[44,45]$ and elevated the total antioxidant activity and bio-accessible lycopene content in tomatoes, although a loss of vitamin $C$ was observed during the thermal treatment process [46]. Adefegha and Oboh [47] reported that cooking tropical green leafy vegetables decreased the vitamin $C$ contents, while it increased the phenolic content and antioxidant activities. Green mature tomato's pretreatment by high-voltage electrostatic field (HVEF), a non-chemical technique applied to food preservation with minimal heat production, significantly reduced the contents of superoxide and hydrogen peroxide of tomato during storage and enhanced the activities of antioxidant enzymes including catalase, superoxide dismutase, ascorbate peroxidase and peroxidase. The contents of non-enzyme antioxidant components including reduced glutathione, phenols and ascorbic acid were also increased by HVEF treatment [48]. Additionally, the technique of high-pressure processing, where a pressure from 40 to $1000 \mathrm{MPa}$ is used for 1 to $20 \mathrm{~min}$, resulted in the increased antioxidant activity of carotenoids in tomatoes and orange juices [49] and even increased lutein bioavailability in green beans [50] as well as quercetin and the antioxidant activity in onions [51].

Table 1. Food preservation technology can increase, decrease or fail to affect the food's antioxidant activity.

\begin{tabular}{|c|c|c|}
\hline \multirow{2}{*}{ Food Preservation Technology } & \multicolumn{2}{|c|}{ Effect on Antioxidants } \\
\hline & Negative & Positive \\
\hline Frozen & $\begin{array}{l}\text { Reduced vitamin } C \text { and free radical } \\
\text { scavenging capacity in raspberries frozen } \\
\text { for more than } 12 \text { months [28]. }\end{array}$ & $\begin{array}{l}\text { Retention of vitamin } C \text { in raspberry } \\
\text { fruit [31]. }\end{array}$ \\
\hline Dehydration & $\begin{array}{l}\text { Reduced antioxidant activity in } \\
\text { Saskatoon berries [32]. }\end{array}$ & \\
\hline Soaking and roasting & & $\begin{array}{l}\text { Increased antioxidant contents in selected } \\
\text { dry beans [33]. }\end{array}$ \\
\hline High-pressure processing & $\begin{array}{l}\text { Reduced antioxidant activity in fruit } \\
\text { smoothies [28]. }\end{array}$ & $\begin{array}{l}\text { Increased antioxidant activity of } \\
\text { carotenoids in tomatoes and orange juices } \\
\text { [49]. Increased lutein bioavailability in } \\
\text { green beans [50] as well as quercetin and } \\
\text { the antioxidant activity in onions [51]. }\end{array}$ \\
\hline $\begin{array}{l}\text { Thermal processing(boiling, } \\
\text { steaming, microwaving) }\end{array}$ & $\begin{array}{c}\text { Reduction up to } 45 \% \text { antioxidant capacity } \\
\text { after processing fruits (cherry, plums, } \\
\text { raspberry) into jams [34]. Loss of vitamin } \\
\text { C in tomato [ } 46 \text { ] and tropical green leafy } \\
\text { vegetables [47]. }\end{array}$ & $\begin{array}{c}\text { Increased antioxidant activity of red beet } \\
\text { [43], tomato [44], sweet corn [45], tropical } \\
\text { green leafy vegetables [47]. }\end{array}$ \\
\hline
\end{tabular}


Table 1. Cont

\begin{tabular}{|c|c|c|}
\hline \multirow{2}{*}{ Food Preservation Technology } & \multicolumn{2}{|c|}{ Effect on Antioxidants } \\
\hline & Negative & Positive \\
\hline High-voltage electrostatic field (HVEF) & & $\begin{array}{l}\text { Enhanced the activity of antioxidant } \\
\text { enzymes including catalase, superoxide } \\
\text { dismutase, ascorbate peroxidase and } \\
\text { peroxidase, and reduced glutathione, } \\
\text { phenols and ascorbic acid [48]. }\end{array}$ \\
\hline$\gamma$-irradiation & $\begin{array}{l}\text { Ascorbate content of the mango fruits } \\
\text { decreased when the dose exceeded } \\
1.5 \mathrm{kGy} \text { [52]. Decrease of vitamin C in } \\
\text { black pepper, cinnamon, nutmeg, } \\
\text { oregano and sage after } 10 \mathrm{kGy} \text { dose [53]. }\end{array}$ & $\begin{array}{c}\text { Increased antioxidant activity in carrot } \\
\text { and kale juice after } 3 \text { days [54]. No } \\
\text { difference in antioxidant activity of } \\
\text { turmeric [55]. No difference in } \\
\text { antioxidative capacity of cinnamon, } \\
\text { ginger, nutmeg, anise, vanilla, licorice, } \\
\text { mint [56]. }\end{array}$ \\
\hline UV-C light & & $\begin{array}{l}\text { Higher antioxidant capacity in peppers } \\
\text { [57], broccoli [58], strawberries [59]. }\end{array}$ \\
\hline UV-B light & & $\begin{array}{l}\text { Apple fruit, increased antioxidant } \\
\text { capacity in peel, no difference in the } \\
\text { flesh [60]. }\end{array}$ \\
\hline Alkaline $\mathrm{pH}$ & $\begin{array}{l}\text { Decreased antioxidant activity of } \\
\text { aqueous medicinal plant extracts } \\
\text { (rosehip: Rosa canina L., golden root: } \\
\text { Rhodiola rosea L., St John's-wort: Hypericum } \\
\text { perforatum L. and the great yellow gentian: } \\
\text { Gentiana lutea L.) [61]. }\end{array}$ & \\
\hline
\end{tabular}

While vitamins $C$ and $E$ are not stable during high-temperature treatments, carotenes [62] and most phenolic compounds become more available in cooked foods [63]. Moreover, the total antioxidant capacity is elevated during the thermal treatment of carotenes and phenolic compounds due to the softening of the food matrix, disruption and degradation of plant cell walls, cellular dehydration and separation of the tissue and release of fibers in fruits and vegetables [63].

\section{The Neglected Positive Health Effects of Oxidized Forms of Nutritional Antioxidants}

Is the antioxidative potential of natural antioxidants the most important biological factor, and does it play a major role in health-beneficial effects? Is the increased amount of oxidative forms of an antioxidant formed during various food processing techniques and storage methods bad on the other hand, from the perspective of human health?

Antioxidants can have dichotomous roles in reactive oxygen species (ROS) production. They are easily oxidized and can act as oxidants to induce damage when present in large concentrations; however, oxidized forms of natural antioxidants are relatively unreactive towards biomolecules. For example, oxidized forms of ascorbate (ascorbate radical and dehydroascorbate) [64,65], phenoxyl radicals [66], tocopheroxyl radicals and lycopene radicals [67] are relatively stable and unreactive and do not cause cellular damage or initiate lipid peroxidation. The damaging free radicals can be generated through Fenton and Haber-Weiss reactions when reduced forms of redox-active metal ions and $\mathrm{H} 2 \mathrm{O} 2$ in the presence of antioxidants produce reactive hydroxyl radicals. The limiting factor inside the cells is the $\mathrm{H}_{2} \mathrm{O}_{2}$ that is formed during the autooxidation of synthetic antioxidants like vitamins C, E and others $[68,69]$. It can reduce free iron $\mathrm{Fe}^{2+}$ and other metal ions (chromium, cobalt, copper and vanadium), which initiate free radical generation through Fenton-like reactions.

Antioxidants are involved in immune responses, cell signaling processes, the regulation of transcription factor activities and other determinants of gene expression [70]. 
Furthermore, ROS interact with cellular signal pathways that control the cell cycle, differentiation and apoptosis [71,72] (Figure 1). Appropriate amounts of oxidized forms of natural antioxidants can modulate cellular metabolism by the induction of cell stress responses and/or the activation of cell damage repair and maintenance systems [73]. Namely, ROS and oxidants are also signaling molecules, e.g., cells use superoxide and hydrogen peroxide as a chemical signal in the regulation of glucose metabolism, cellular growth, proliferation and cell defense against pathogens [74]. Even some lipid peroxidation products modulate signal transduction pathways and induce an adaptive response by upregulating defense processes [75]. An increase in oxidants or ROS can activate the extracellular signal-related protein kinase (ERK), protein kinase B, mitogen-activated protein kinases (MAPKs), insulin receptor kinase and other adaptive stress response pathways like redox-sensitive transcription factors, e.g., nuclear factor-kB (NF-kB) and Activator Protein-1 (AP-1) [76-79]. Various intracellular redox sensors monitor the redox balance within the cell by detecting the levels of reduced NADH and quinones, the reduced and oxidized glutathione ratio (GSH/GSSG); they can sense the oxidation of reduced species of proteins and low molecular thiols as well as the molecular oxygen levels, reactive nitrogen oxide species (RNOS) amounts [80] and an increase in superoxide, hydrogen peroxide and other ROS. Numerous intracellular signaling pathways are activated by triggering alterations in transcription as a response to increased intracellular oxidation; e.g., direct oxidation and reduction of transcription factors that occur with OxyR or in the APE-1/Ref-1 system, changed subcellular localization of both Nrf2/Keap1 and Yap1 and alterations of intracellular redox buffers that, in turn, modulate the activity of chromatin-modifying enzymes such as SIRT1 or alter the binding of NADH-dependent transcription factors such as BMAL [81]. Moderate concentrations of ROS are essential mediators of defense against pathogens and unwanted cells; the latter is important in cancer prevention [82]. If the administration of antioxidant supplements decreases ROS, it may also interfere with apoptosis and attenuate the elimination of damaged cells, including those that are precancerous and cancerous [83]. Therefore, the excessive neutralization of free radicals by antioxidant supplementation interferes with essential mechanisms of cellular defense and repair [83] and induces so-called "antioxidative stress" (reviewed in Poljsak and Milisav [84]). Oxidized forms of antioxidants at low doses induce the effect of hormesis resulting in increased cellular defense by activating the increased endogenous antioxidant protection and damage repair processes. Hormesis is an adaptive response to a low-intensity stressor exposure that causes an initial disruption in homeostasis [85]. Based on the classical physiological concept of hormesis, Finkel and Holbrook [86] suggested that the best strategy to enhance endogenous antioxidant levels may be oxidative stress itself.

It was observed in some antioxidant-rich beverages, like green tea, black tea and coffee [87-90], that $\mathrm{H}_{2} \mathrm{O}_{2}$ and superoxide radicals are generated during the auto-oxidation of natural antioxidants under aerobic quasi-physiological conditions [91-93]. Ingested low levels of $\mathrm{H}_{2} \mathrm{O}_{2}$ can activate stress response survival pathways [70]. The observed beneficial effects of tea and coffee drinking may be attributed to the ROS-induced mild oxidative stress that triggers cellular adaptive responses [94]. On the contrary, ingesting large doses of exogenous antioxidants can interfere with signaling pathways that regulate cell proliferation, differentiation and apoptosis [95], as well as with the synthesis rate of endogenous antioxidants, like SOD and catalase [96-98]; their activity may also be decreased. Large amounts of antioxidant nutrients can increase the oxidative stress in the presence of metal ions due to the Fenton-like chemical reactions $[99,100]$, as antioxidants in their reduced form can induce increased ROS formation or other pro-oxidant effects in the presence of free redox cycling metal ions. 


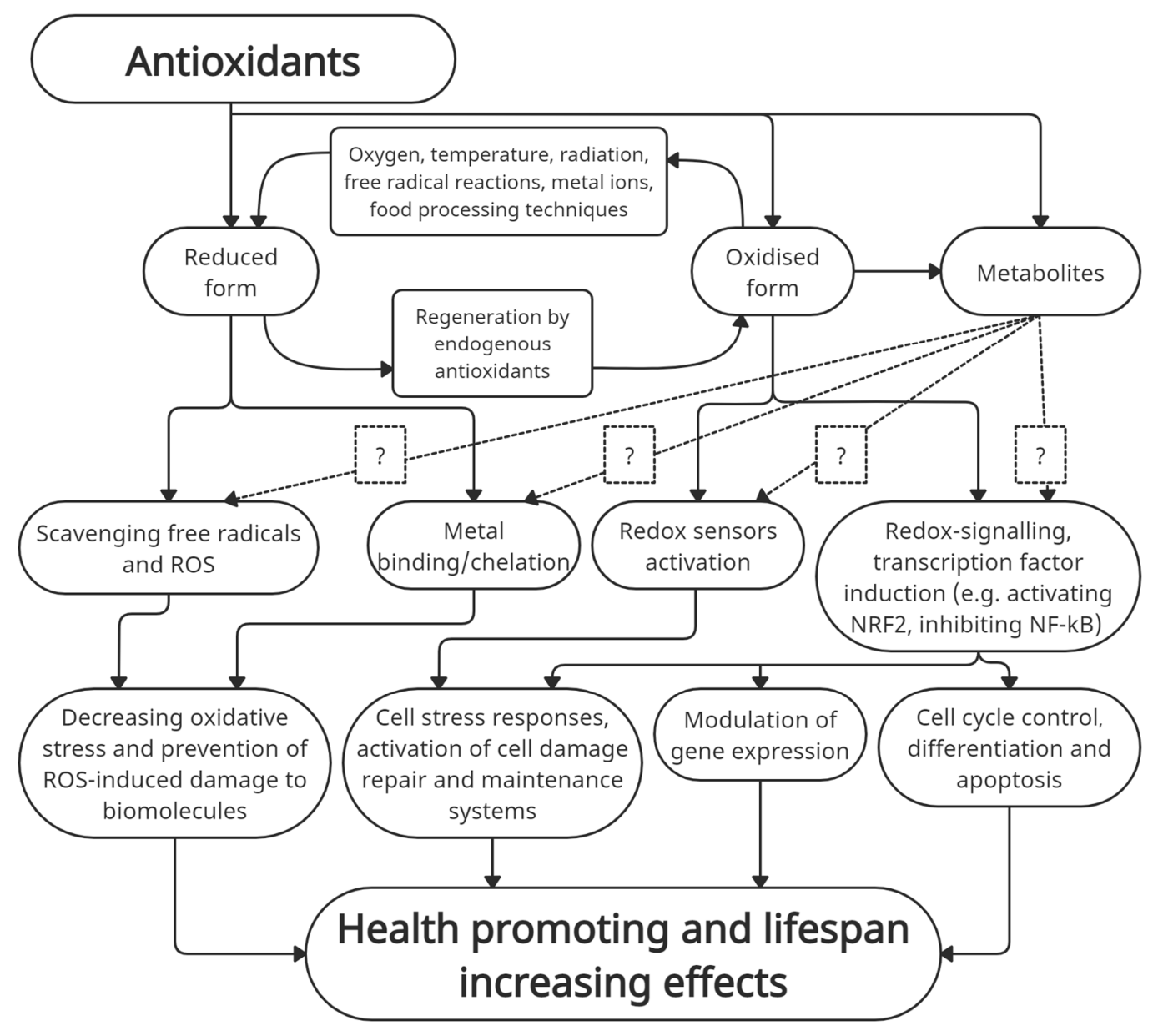

Figure 1. The health-promoting roles of antioxidants and their metabolites.

Although the oxidized forms of natural antioxidants may initially deplete endogenous antioxidants (e.g., glutathione), they may also increase the activity of endogenous defense and repair systems as a consequence of the endogenous antioxidants' regeneration [101]. For example, Hopkins and Morgan [102], Packer and coworkers [103] and May and coworkers [101] demonstrated that ascorbate can regenerate oxidized vitamin E and GSH can regenerate oxidized ascorbate. On the other hand, the ingestion of exogenous antioxidants can interfere with the synthesis of the endogenous antioxidants by suppressing their formation. For example, nutritive antioxidants completely abolished the extension of lifespan by inhibiting an adaptive reaction to ROS called mitohormesis [104,105]. Similarly, reduced health-promoting effects were demonstrated if the subjects exposed to physical activity were treated with antioxidant supplements $[106,107]$. Supplementation with some antioxidants (e.g., vitamin $\mathrm{E}$ and $\alpha$-lipoic acid) suppresses skeletal muscle mitochondrial biogenesis, regardless of the training status [108]. Antioxidant therapy with vitamins A, C and $\mathrm{E}$ and resveratrol can also suppress the synthesis of endogenous antioxidants, thus preventing the beneficial effects obtained with regular exercise $[107,109]$, most probably due to the reduced mitochondrial biogenesis that is stimulated by excessive ROS formation [108]. What is more, supplementation with antioxidants or radical-scavenging supplements could neutralize the ROS that trigger the release of Nrf2 and consequently hormesis during moderate cell stress. Antioxidant supplementation buffers ROS and thus "turns off" the hormesis when the cells' stress is within the hormesis-inducing range [73].

An important aspect of oxidized forms of natural antioxidants is their cellular uptake. Although few studies investigated this concept, it seems that some antioxidants penetrate cells more sufficiently and faster in their oxidized form. Such an example is vitamin C, through sodium-independent dehydroascorbic acid transport [110]. Dehydroascorbic 
acid is transported into cells through the glucose transporters Glut1 and Glut2 [111]. The oxidized form of ascorbic acid (dehydroascorbate) is regenerated by intracellular glutathione [112]. Furthermore, an antioxidant silybin, 2,3-dehydrosilybin (DHS), in its oxidized form, enters cells faster, induces adaptive responses and increases tolerance against forthcoming oxidative stress by upregulating endogenous defenses and signaling pathways [113].

\section{Discussion}

The antioxidant activity of fruits and vegetables depends on the type of vegetable/fruit and the processing technology used. The processing approach can decrease, increase or fail to affect the antioxidative content of foods. Emerging technologies, such as high hydrostatic pressure, pulsed electric field, ultrasound, microwave, ohmic heating and irradiation, are being studied as an alternative to the conventional ones in retaining the health benefits of antioxidant compounds in processed food products $[44,114]$. In general, non-thermal food treatments such as gamma and ultraviolet irradiation, ultraviolet light, pulsed electric fields and high hydrostatic pressure are better in retaining the quality of the bioactive compounds in plant-based foods, while thermal treatments can induce the formation of compounds with new antioxidant properties (e.g., Maillard reaction products) and improve bioavailability (of e.g., carotenes).

We discussed whether the formation of oxidized forms of natural antioxidants during food processing and storage can affect health. Namely, excessive synthetic antioxidant intake (e.g., by ingesting food supplements or adding synthetic antioxidants in food) can alter the endogenous antioxidative defense of cells or cell death pathways as well as suppress the synthesis of endogenous antioxidants [107,109,115]. An increase in cellular antioxidants can trigger increased ROS formation or neutralize free radicals and cause redox dysregulation and signal transduction. A nonselective elimination of free radicals by synthetic antioxidants is more likely to disrupt, rather than extend, the normal cell function. Some compounds with antioxidant activities may improve health, not due to their antioxidant properties, but because of their role in damage repair stimulation and, paradoxically, because of their pro-oxidant activity. The efficiency of defense and repair may be enhanced after the exposure to "moderate" levels of ROS or oxidants, since the expression of many DNA repair enzymes is upregulated during mild oxidative stress or other kinds of stresses [104,116,117].

Low and intermittent doses of oxidants can have a long-term effect on health promotion and life-span increase due to the activation of adaptive response processes and an increase in the synthesis of antioxidant and other defense and repair systems [2]. The beneficial physiological use of ROS is now being demonstrated in different fields, including intracellular signaling and redox regulation. The duration of life-span and health-span may thus be improved by activating the signaling pathways that boost cellular repair and maintenance processes, also with oxidized forms of antioxidants formed during the food processing.

\section{Conclusions}

While a chemical conversion from the reduced to an oxidized form of an antioxidant is an unwanted process, formed during food processing, as regards food quality and nutritional value, such transformation may sometimes result in as yet neglected health benefits. The reduction or increase of phytochemicals does not necessarily result in increased antioxidant activity, and increased antioxidant activity is not always beneficial. Functional studies determining the antioxidant effects on the organisms are important, especially as reduced or oxidized antioxidants and their metabolites may have additional or synergistic effects. As relatively little is known about the cellular effects of oxidized forms of antioxidants, future studies should also evaluate the pro-oxidant activity of vegetables, fruits, culinary herbs and spices and the formation of compounds during food processing and their effect on human health and disease prevention. 
Author Contributions: B.P. and I.M. conception, data acquisition, drafting and revising the work, V.K. data acquisition and drafting the work. All authors have read and agreed to the published version of the manuscript.

Funding: This research was funded by the Slovenian Research Agency, Research Core Funding No. P3-0388 and P3-0019.

Conflicts of Interest: The authors declare no conflict of interest.

\section{References}

1. Lindley, M.G. The impact of food processing on antioxidants in vegetable oils, fruits and vegetables. Trends Food Sci. Technol. 1998, 9, 336-340. [CrossRef]

2. Halliwell, B.; Gutteridge, J.M.C. Free Radicals in Biology and Medicine; Oxford University Press: Oxford, UK, 2015.

3. Harasym, J.; Oledzki, R. Effect of fruit and vegetable antioxidants on total antioxidant capacity of blood plasma. Nutrition 2014, 30, 511-517. [CrossRef] [PubMed]

4. Halliwell, B.; Gutteridge, J.M.C.; Cross, C.E. Free radicals, antioxidants, and human disease: Where are we now? J. Lab. Clin. Med. 1992, 119, 598-620. [PubMed]

5. Traka, M.H.; Mithen, R.F. Plant science and human nutrition: Challenges in assessing health-promoting properties of phytochemicals. Plant Cell 2011, 23, 2483-2497. [CrossRef] [PubMed]

6. Boeing, H.; Bechthold, A.; Bub, A.; Ellinger, S.; Haller, D.; Kroke, A.; Leschik-Bonnet, E.; Müller, M.J.; Oberritter, H.; Schulze, M.; et al. Critical review: Vegetables and fruit in the prevention of chronic diseases. Eur. J. Nutr. 2012, 51, 637-663. [CrossRef] [PubMed]

7. Kaur, C.; Kapoor, H.C. Antioxidants in fruits and vegetables-The millennium's health. Int. J. Food Sci. Technol. 2008, 36, 703-725. [CrossRef]

8. Bellavia, A.; Larsson, S.C.; Bottai, M.; Wolk, A.; Orsini, N. Fruit and vegetable consumption and all-cause mortality: A doseresponse analysis. Am. J. Clin. Nutr. 2013, 98, 454-459. [CrossRef] [PubMed]

9. Zhan, J.; Liu, Y.J.; Cai, L.B.; Xu, F.R.; Xie, T.; He, Q.Q. Fruit and vegetable consumption and risk of cardiovascular disease: A meta-analysis of prospective cohort studies. Crit. Rev. Food Sci. Nutr. 2017, 57, 1650-1663. [CrossRef]

10. Aguilera, Y.; Martin-Cabrejas, M.A.; González de Mejia, E. Phenolic compounds in fruits and beverages consumed as part of the mediterranean diet: Their role in prevention of chronic diseases. Phytochem. Rev. 2016, 15, 405-423. [CrossRef]

11. Hartley, L.; Igbinedion, E.; Holmes, J.; Flowers, N.; Thorogood, M.; Clarke, A.; Stranges, S.; Hooper, L.; Rees, K. Increased consumption of fruit and vegetables for the primary prevention of cardiovascular diseases. Cochrane Database Syst. Rev. $2013,2013$. [CrossRef]

12. Argüelles, S.; Gómez, A.; Machado, A.; Ayala, A. A preliminary analysis of within-subject variation in human serum oxidative stress parameters as a function of time. Rejuvenation Res. 2007, 10, 621-636. [CrossRef]

13. Pokorný, J.; Schmidt, Š. Natural antioxidant functionality during food processing. In Antioxidants in Food; Elsevier: Amsterdam, The Netherlands, 2001; pp. 331-354.

14. Shan, B.; Cai, Y.Z.; Sun, M.; Corke, H. Antioxidant capacity of 26 spice extracts and characterization of their phenolic constituents. J. Agric. Food Chem. 2005, 53, 7749-7759. [CrossRef]

15. Srinivasan, K. Antioxidant Potential of Spices and Their Active Constituents. Crit. Rev. Food Sci. Nutr. 2014, 54, 352-372. [CrossRef]

16. Paur, I.; Carlsen, M.H.; Halvorsen, B.L.; Blomhoff, R. Antioxidants in Herbs and Spices: Roles in Oxidative Stress and Redox Signaling-PubMed, 2nd ed.; Benzie Iris, F.F., Wachtel-Galor, S., Eds.; Tayor \& Francis: Boca Raton, FL, USA, 2011.

17. Yashin, A.; Yashin, Y.; Xia, X.; Nemzer, B. Antioxidant activity of spices and their impact on human health: A review. Antioxidants 2017, 6, 70. [CrossRef] [PubMed]

18. Huang, D. Dietary antioxidants and health promotion. Antioxidants 2018, 7,9. [CrossRef]

19. Zheng, W.; Wang, S.Y. Antioxidant activity and phenolic compounds in selected herbs. J. Agric. Food Chem. 2001, 49, 5165-5170. [CrossRef]

20. Pizzale, L.; Bortolomeazzi, R.; Vichi, S.; Überegger, E.; Conte, L.S. Antioxidant activity of sage (Salvia officinalis and S fruticosa) and oregano (Origanum onites and O indercedens) extracts related to their phenolic compound content. J. Sci. Food Agric. 2002, 82, 1645-1651. [CrossRef]

21. Embuscado, M.E. Spices and herbs: Natural sources of antioxidants-A mini review. J. Funct. Foods 2015, 18, 811-819. [CrossRef]

22. Rutkowska, J.; Antoniewska, A.; Martinez-Pineda, M.; Nawirska-Olszańska, A.; Zbikowska, A.; Baranowski, D. Black chokeberry fruit polyphenols: A valuable addition to reduce lipid oxidation of muffins containing xylitol. Antioxidants 2020, 9, 394. [CrossRef] [PubMed]

23. Kozłowska, M.; Żbikowska, A.; Gruczyńska, E.; Żontała, K.; Półtorak, A. Effects of spice extracts on lipid fraction oxidative stability of cookies investigated by DSC. J. Therm. Anal. Calorim. 2014, 118, 1697-1705. [CrossRef]

24. Kozłowska, M.; Żbikowska, A.; Szpicer, A.; Półtorak, A. Oxidative stability of lipid fractions of sponge-fat cakes after green tea extracts application. J. Food Sci. Technol. 2019, 56, 2628-2638. [CrossRef] 
25. Eric, D.; Rayan, E.; McClemens, J.D. (Eds.) Oxidation in Foods and Beverages and Antioxidant Applications, 1st ed.; Woodhead Publishing: Oxford, UK, 2010.

26. Alothman, M.; Bhat, R.; Karim, A.A. Effects of radiation processing on phytochemicals and antioxidants in plant produce. Trends Food Sci. Technol. 2009, 20, 201-212. [CrossRef]

27. Al-juhaimi, F.; Ghafoor, K.; Özcan, M.M.; Jahurul, M.H.A.; Babiker, E.E.; Jinap, S.; Sahena, F.; Sharifudin, M.S.; Zaidul, I.S.M. Effect of various food processing and handling methods on preservation of natural antioxidants in fruits and vegetables. J. Food Sci. Technol. 2018, 55, 3872-3880. [CrossRef]

28. Keenan, D.F.; Brunton, N.P.; Gormley, T.R.; Butler, F.; Tiwari, B.K.; Patras, A. Effect of thermal and high hydrostatic pressure processing on antioxidant activity and colour of fruit smoothies. Innov. Food Sci. Emerg. Technol. 2010, 11, 551-556. [CrossRef]

29. Wachtel-Galor, S.; Wong, K.W.; Benzie, I.F.F. The effect of cooking on Brassica vegetables. Food Chem. 2008, 110, 706-710. [CrossRef]

30. Somsub, W.; Kongkachuichai, R.; Sungpuag, P.; Charoensiri, R. Effects of three conventional cooking methods on vitamin C, tannin, myo-inositol phosphates contents in selected Thai vegetables. J. Food Compos. Anal. 2008, 21, 187-197. [CrossRef]

31. De Ancos, B.; Gonzalez, E.M.; Cano, M.P. Ellagic acid, vitamin C, and total phenolic contents and radical scavenging capacity affected by freezing and frozen storage in raspberry fruit. J. Agric. Food Chem. 2000, 48, 4565-4570. [CrossRef] [PubMed]

32. Kwok, B.H.L.; Hu, C.; Durance, T.; Kitts, D.D. Dehydration Techniques Affect Phytochemical Contents and Free Radical Scavenging Activities of Saskatoon berries (Amelanchier alnifolia Nutt.). J. Food Sci. 2006, 69, SNQ122-SNQ126. [CrossRef]

33. Boateng, J.; Verghese, M.; Walker, L.T.; Ogutu, S. Effect of processing on antioxidant contents in selected dry beans (Phaseolus spp. L.). LWT Food Sci. Technol. 2008, 41, 1541-1547. [CrossRef]

34. Kim, D.-O.; Padilla-Zakour, O.I. Jam Processing Effect on Phenolics and Antioxidant Capacity in Anthocyanin-rich Fruits: Cherry, Plum, and Raspberry. J. Food Sci. 2006, 69, S395-S400. [CrossRef]

35. Horvathova, J.; Suhaj, M.; Simko, P. Effect of thermal treatment and storage on antioxidant activity of some spices. J. Food Nutr. Res. 2007, 46, 20-27.

36. Nicoli, M.C.; Anese, M.; Parpinel, M. Influence of processing on the antioxidant properties of fruit and vegetables. Trends Food Sci. Technol. 1999, 10, 94-100. [CrossRef]

37. Hidalgo, F.J.; Zamora, R. Food Processing Antioxidants. In Advances in Food and Nutrition Research; Academic Press Inc.: Cambridge, MA, USA, 2017; Volume 81, pp. 31-64.

38. Turkmen, N.; Sari, F.; Velioglu, Y.S. The effect of cooking methods on total phenolics and antioxidant activity of selected green vegetables. Food Chem. 2005, 93, 713-718. [CrossRef]

39. Miglio, C.; Chiavaro, E.; Visconti, A.; Fogliano, V.; Pellegrini, N. Effects of different cooking methods on nutritional and physicochemical characteristics of selected vegetables. J. Agric. Food Chem. 2008, 56, 139-147. [CrossRef]

40. Ng, Z.X.; Chai, J.W.; Kuppusamy, U.R. Customized cooking method improves total antioxidant activity in selected vegetables. Int. J. Food Sci. Nutr. 2011, 62, 158-163. [CrossRef] [PubMed]

41. Chuah, A.M.; Lee, Y.C.; Yamaguchi, T.; Takamura, H.; Yin, L.J.; Matoba, T. Effect of cooking on the antioxidant properties of coloured peppers. Food Chem. 2008, 111, 20-28. [CrossRef]

42. Dini, I.; Tenore, G.C.; Dini, A. Effect of industrial and domestic processing on antioxidant properties of pumpkin pulp. LWT Food Sci. Technol. 2013, 53, 382-385. [CrossRef]

43. Ravichandran, K.; Saw, N.M.M.T.; Mohdaly, A.A.A.; Gabr, A.M.M.; Kastell, A.; Riedel, H.; Cai, Z.; Knorr, D.; Smetanska, I. Impact of processing of red beet on betalain content and antioxidant activity. Food Res. Int. 2013, 50, 670-675. [CrossRef]

44. Nayak, B.; Liu, R.H.; Tang, J. Effect of Processing on Phenolic Antioxidants of Fruits, Vegetables, and Grains-A Review. Crit. Rev. Food Sci. Nutr. 2015, 55, 887-918. [CrossRef]

45. Dewanto, V.; Wu, X.; Liu, R.H. Processed sweet corn has higher antioxidant activity. J. Agric. Food Chem. 2002, 50, 4959-4964. [CrossRef]

46. Dewanto, V.; Xianzhong, W.; Adom, K.K.; Liu, R.H. Thermal processing enhances the nutritional value of tomatoes by increasing total antioxidant activity. J. Agric. Food Chem. 2002, 50, 3010-3014. [CrossRef]

47. Adefegha, A.S.; Oboh, G. Cooking enhances the antioxidant properties of some tropical green leafy vegetables. Afr. J. Biotechnol. 2011, 10, 623-639.

48. Zhao, R.; Hao, J.; Xue, J.; Liu, H.; Li, L. Effect of high-voltage electrostatic field pretreatment on the antioxidant system in stored green mature tomatoes. J. Sci. Food Agric. 2011, 91, 1680-1686. [CrossRef]

49. McInerney, J.K.; Seccafien, C.A.; Stewart, C.M.; Bird, A.R. Effects of high pressure processing on antioxidant activity, and total carotenoid content and availability, in vegetables. Innov. Food Sci. Emerg. Technol. 2007, 8, 543-548. [CrossRef]

50. van het Hof, K.H.; Brouwer, I.A.; West, C.E.; Haddeman, E.; Steegers-Theunissen, R.P.; van Dusseldorp, M.; Weststrate, J.A.; Eskes, T.K.; Hautvast, J.G. Bioavailability of lutein from vegetables is 5 times higher than that of $\beta$-carotene. Am. J. Clin. Nutr. 1999, 70, 261-268. [CrossRef]

51. Roldán-Marín, E.; Sánchez-Moreno, C.; Lloría, R.; de Ancos, B.; Cano, M.P. Onion high-pressure processing: Flavonol content and antioxidant activity. LWT Food Sci. Technol. 2009, 42, 835-841. [CrossRef]

52. Reyes, L.F.; Cisneros-Zevallos, L. Electron-beam ionizing radiation stress effects on mango fruit (Mangifera indica L.) antioxidant constituents before and during postharvest storage. J. Agric. Food Chem. 2007, 55, 6132-6139. [CrossRef] [PubMed] 
53. Calucci, L.; Pinzino, C.; Zandomeneghi, M.; Capocchi, A.; Ghiringhelli, S.; Saviozzi, F.; Tozzi, S.; Galleschi, L. Effects of $\gamma-$ irradiation on the free radical and antioxidant contents in nine aromatic herbs and spices. J. Agric. Food Chem. 2003, 51, 927-934. [CrossRef]

54. Song, H.P.; Kim, D.H.; Jo, C.; Lee, C.H.; Kim, K.S.; Byun, M.W. Effect of gamma irradiation on the microbiological quality and antioxidant activity of fresh vegetable juice. Food Microbiol. 2006, 23, 372-378. [CrossRef]

55. Almeida, M.C.; Sampaio, G.R.; Bastos, D.H.M.; Villavicencio, A.L.C.H. Effect of gamma radiation processing on turmeric: Antioxidant activity and curcumin content. Radiat. Phys. Chem. 2018, 152, 12-16. [CrossRef]

56. Murcia, M.A.; Egea, I.; Romojaro, F.; Parras, P.; Jiménez, A.M.; Martínez-Tomé, M. Antioxidant Evaluation in Dessert Spices Compared with Common Food Additives. Influence of Irradiation Procedure. J. Agric. Food Chem. 2004, 52, 1872-1881. [CrossRef]

57. Vicente, A.R.; Pineda, C.; Lemoine, L.; Civello, P.M.; Martinez, G.A.; Chaves, A.R. UV-C treatments reduce decay, retain quality and alleviate chilling injury in pepper. Postharvest Biol. Technol. 2005, 35, 69-78. [CrossRef]

58. Costa, L.; Vicente, A.R.; Civello, P.M.; Chaves, A.R.; Martínez, G.A. UV-C treatment delays postharvest senescence in broccoli florets. Postharvest Biol. Technol. 2006, 39, 204-210. [CrossRef]

59. Erkan, M.; Wang, S.Y.; Wang, C.Y. Effect of UV treatment on antioxidant capacity, antioxidant enzyme activity and decay in strawberry fruit. Postharvest Biol. Technol. 2008, 48, 163-171. [CrossRef]

60. Hagen, S.F.; Borge, G.I.A.; Bengtsson, G.B.; Bilger, W.; Berge, A.; Haffner, K.; Solhaug, K.A. Phenolic contents and other health and sensory related properties of apple fruit (Malus domestica Borkh., cv. Aroma): Effect of postharvest UV-B irradiation. Postharvest Biol. Technol. 2007, 45, 1-10. [CrossRef]

61. Bayliak, M.M.; Burdyliuk, N.I.; Lushchak, V.I. Effects of $\mathrm{pH}$ on antioxidant and prooxidant properties of common medicinal herbs. Open Life Sci. 2016, 11, 298-307. [CrossRef]

62. Rock, C.L.; Lovalvo, J.L.; Emenhiser, C.; Ruffin, M.T.; Flatt, S.W.; Schwartz, S.J. Bioavailability of $\beta$-carotene is lower in raw than in processed carrots and spinach in women. J. Nutr. 1998, 128, 913-916. [CrossRef] [PubMed]

63. Paciulli, M.; Ganino, T.; Carini, E.; Pellegrini, N.; Pugliese, A.; Chiavaro, E. Effect of different cooking methods on structure and quality of industrially frozen carrots. J. Food Sci. Technol. 2016, 53, 2443-2451. [CrossRef]

64. Flora, S.J.S. Structural, chemical and biological aspects of antioxidants for strategies against metal and metalloid exposure. Oxid. Med. Cell. Longev. 2009, 2, 191-206. [CrossRef] [PubMed]

65. Tu, Y.J.; Njus, D.; Schlegel, H.B. A theoretical study of ascorbic acid oxidation and HOO/O 2-Radical scavenging. Org. Biomol. Chem. 2017, 15, 4417-4431. [CrossRef] [PubMed]

66. Hermund, D.B. Antioxidant Properties of Seaweed-Derived Substances; Elsevier: Amsterdam, The Netherlands, 2018 ; pp. $201-221$.

67. Moussa, Z.; Judeh, Z.M.; Ahmed, S.A. Nonenzymatic Exogenous and Endogenous Antioxidants. In Free Radical Medicine and Biology; IntechOpen: London, UK, 2019.

68. Dinkova-Kostova, A.T.; Holtzclaw, W.D.; Cole, R.N.; Itoh, K.; Wakabayashi, N.; Katoh, Y.; Yamamoto, M.; Talalay, P. Direct evidence that sulfhydryl groups of Keap1 are the sensors regulating induction of phase 2 enzymes that protect against carcinogens and oxidants. Proc. Natl. Acad. Sci. USA 2002, 99, 11908-11913. [CrossRef]

69. Balogun, E.; Hoque, M.; Gong, P.; Killeen, E.; Green, C.J.; Foresti, R.; Alam, J.; Motterlini, R. Curcumin activates the haem oxygenase-1 gene via regulation of Nrf2 and the antioxidant-responsive element. Biochem. J. 2003, 371, 887-895. [CrossRef] [PubMed]

70. Poljsak, B.; Milisav, I. Oxidized forms of dietary antioxidants: Friends or foes? Trends Food Sci. Technol. 2014, 39, 156-166. [CrossRef]

71. Redza-Dutordoir, M.; Averill-Bates, D.A. Activation of apoptosis signalling pathways by reactive oxygen species. Biochim. Biophys. Acta Mol. Cell Res. 2016, 1863, 2977-2992. [CrossRef]

72. Espinosa-Diez, C.; Miguel, V.; Mennerich, D.; Kietzmann, T.; Sánchez-Pérez, P.; Cadenas, S.; Lamas, S. Antioxidant responses and cellular adjustments to oxidative stress. Redox Biol. 2015, 6, 183-197. [CrossRef]

73. Milisav, I.; Ribarič, S.; Poljsak, B. Antioxidant vitamins and ageing. In Subcellular Biochemistry; Springer: New York, NY, USA, 2018; Volume 90, pp. 1-23.

74. Rhee, S.G. Redox signaling: Hydrogen peroxide as intracellular messenger. Exp. Mol. Med. 1999, 31, 53-59. [CrossRef] [PubMed]

75. Chen, Z.; Niki, E. Two faces of lipid peroxidation products: The -Yin and Yang- principles of oxidative stress. J. Exp. Integr. Med. 2011, 1, 215. [CrossRef]

76. Valko, M.; Leibfritz, D.; Moncol, J.; Cronin, M.T.D.; Mazur, M.; Telser, J. Free radicals and antioxidants in normal physiological functions and human disease. Int. J. Biochem. Cell Biol. 2007, 39, 44-84. [CrossRef]

77. Afanas'ev, I.B. Free radical mechanisms of aging processes under physiological conditions. Biogerontology 2005, 6, 283-290. [CrossRef] [PubMed]

78. Afanas'ev, I.B. Signaling functions of free radicals superoxide \& nitric oxide under physiological \& pathological conditions. Mol. Biotechnol. 2007, 37, 2-4. [PubMed]

79. Liaudet, L.; Vassalli, G.; Pacher, P. Role of peroxynitrite in the redox regulation of cell signal transduction pathways. Front. Biosci. 2009, 14, 4809-4814. [CrossRef] [PubMed]

80. Green, J.; Paget, M.S. Bacterial redox sensors. Nat. Rev. Microbiol. 2004, 2, 954-966. [CrossRef]

81. Liu, H.; Colavitti, R.; Rovira, I.I.; Finkel, T. Redox-dependent transcriptional regulation. Circ. Res. 2005, 97, 967-974. [CrossRef] [PubMed] 
82. Poljsak, B.; Milisav, I. The Role of Antioxidants in Cancer, Friends or Foes? Curr. Pharm. Des. 2019, 24, 5234-5244. [CrossRef]

83. Salganik, R.I. The Benefits and Hazards of Antioxidants: Controlling Apoptosis and Other Protective Mechanisms in Cancer Patients and the Human Population. J. Am. Coll. Nutr. 2001, 20, S464-S472. [CrossRef]

84. Poljsak, B.; Milisav, I. The neglected significance of "antioxidative stress". Oxid. Med. Cell. Longev. 2012, 2012, 1-12. [CrossRef]

85. Mattson, M.P. Dietary factors, hormesis and health. Ageing Res. Rev. 2008, 7, 43-48. [CrossRef] [PubMed]

86. Finkel, T.; Holbrook, N.J. Oxidants, oxidative stress and the. Nature 2000, 408, 239-247. [CrossRef] [PubMed]

87. Akagawa, M.; Shigemitsu, T.; Suyama, K. Production of hydrogen peroxide by polyphenols and polyphenol-rich beverages under quasi-physiological conditions. Biosci. Biotechnol. Biochem. 2003, 67, 2632-2640. [CrossRef] [PubMed]

88. Long, L.H.; Halliwell, B. Coffee drinking increases levels of urinary hydrogen peroxide detected in healthy human volunteers Free Radic. Res. 2000, 32, 463-467. [CrossRef]

89. Fujita, Y.; Wakabayashi, K.; Nagao, M.; Sugimura, T. Implication of hydrogen peroxide in the mutagenicity of coffee. Mutat. Res. Lett. 1985, 144, 227-230. [CrossRef]

90. Szeto, Y.T.; Tomlinson, B.; Benzie, I.F.F. Total antioxidant and ascorbic acid content of fresh fruits and vegetables: Implications for dietary planning and food preservation. Br. J. Nutr. 2002, 87, 55-59. [CrossRef]

91. Poljšak, B.; Gazdag, Z.; Jenko-Brinovec, Š.; Fujs, Š.; Pesti, M.; Bélagyi, J.; Plesničar, S.; Raspor, P. Pro-oxidative vs antioxidative properties of ascorbic acid in chromium(VI)-induced damage: An in vivo and in vitro approach. J. Appl. Toxicol. 2005, 25, 535-548. [CrossRef]

92. Ionescu, J.G.; Novotny, J.; Stejskal, V.; Lätsch, A.; Blaurock-Busch, E.; Eisenmann-Klein, M. Increased levels of transition metals in Breast Cancer Tissue. Neuro Endocrinol. Lett. 2006, 27, 36-39.

93. Anderson, D.; Phillips, B. Comparative In Vitro and In Vivo Effects of Antioxidants. Food Chem. Toxicol. 1999, $37,1015-1025$. [CrossRef]

94. Nehlig, A.; Debry, G. Potential teratogenic and neurodevelopmental consequences of coffee and caffeine exposure: A review on human and animal data. Neurotoxicol. Teratol. 1994, 16, 531-543. [CrossRef]

95. Janssen-Heininger, Y.M.W.; Mossman, B.T.; Heintz, N.H.; Forman, H.J.; Kalyanaraman, B.; Finkel, T.; Stamler, J.S.; Rhee, S.G.; van der Vliet, A. Redox-based regulation of signal transduction: Principles, pitfalls, and promises. Free Radic. Biol. Med. 2008, 45, 1-17. [CrossRef] [PubMed]

96. Zeidán-Chuliá, F.; Gelain, D.P.; Kolling, E.A.; Rybarczyk-Filho, J.L.; Ambrosi, P.; Resende Terra, S.; Pires, A.S.; Da Rocha, J.B.T.; Antônio Behr, G.; Fonseca Moreira, J.C. Major components of energy drinks (caffeine, taurine, and guarana) exert cytotoxic effects on human neuronal SH-SY5Y cells by decreasing reactive oxygen species production. Oxid. Med. Cell. Longev. $2013,2013$. [CrossRef]

97. Cutler, R.G.; Rodriguez, H.; Cutler, R.G.; Mattson, M.P. Measuring Oxidative Stress and Interpreting Its Clinical Relevance for Humans. In Critical Reviews of Oxidative Stress and Aging; World Scientific: Singapore, 2002; pp. 131-164.

98. Cutler, R.G.; Rodriguez, H.; Cutler, R.G. Genetic Stability, Dysdifferentiation, and Longevity Determinant Genes. In Critical Reviews of Oxidative Stress and Aging; World Scientific: Singapore, 2002; pp. 1146-1235.

99. Podmore, I.D.; Griffiths, H.R.; Herbert, K.E.; Mistry, N.; Mistry, P.; Lunec, J. Vitamin C exhibits pro-oxidant properties. Nature 1998, 392, 559. [CrossRef] [PubMed]

100. Palozza, P. Prooxidant actions of carotenoids in biologic systems. Nutr. Rev. 1998, 56, 257-265. [CrossRef]

101. May, J.M.; Mendiratta, S.; Qu, Z.C.; Loggins, E. Vitamin C recycling and function in human monocytic U-937 cells. Free Radic. Biol. Med. 1999, 26, 1513-1523. [CrossRef]

102. Hopkins, F.G.; Morgan, E.J. Some relations between ascorbic acid and glutathione. Biochem. J. 1936, 30, 1446-1462. [CrossRef]

103. Packer, J.E.; Slater, T.F.; Willson, R.L. Direct observation of a free radical interaction between vitamin E and vitamin C [13]. Nature 1979, 278, 737-738. [CrossRef]

104. Schulz, T.J.; Zarse, K.; Voigt, A.; Urban, N.; Birringer, M.; Ristow, M. Glucose Restriction Extends Caenorhabditis elegans Life Span by Inducing Mitochondrial Respiration and Increasing Oxidative Stress. Cell Metab. 2007, 6, 280-293. [CrossRef]

105. Ristow, M.; Schmeisser, S. Extending life span by increasing oxidative stress. Free Radic. Biol. Med. 2011, 51, 327-336. [CrossRef] [PubMed]

106. Ristow, M.; Zarse, K.; Oberbach, A.; Klöting, N.; Birringer, M.; Kiehntopf, M.; Stumvoll, M.; Kahn, C.R.; Blüher, M. Antioxidants prevent health-promoting effects of physical exercise in humans. Proc. Natl. Acad. Sci. USA 2009, 106, 8665-8670. [CrossRef] [PubMed]

107. Gomez-Cabrera, M.C.; Domenech, E.; Romagnoli, M.; Arduini, A.; Borras, C.; Pallardo, F.V.; Sastre, J.; Viña, J. Oral administration of vitamin $C$ decreases muscle mitochondrial biogenesis and hampers training-induced adaptations in endurance performance. Am. J. Clin. Nutr. 2008, 87, 142-149. [CrossRef]

108. Strobel, N.A.; Peake, J.M.; Matsumoto, A.; Marsh, S.A.; Coombes, J.S.; Wadley, G.D. Antioxidant supplementation reduces skeletal muscle mitochondrial biogenesis. Med. Sci. Sports Exerc. 2011, 43, 1017-1024. [CrossRef] [PubMed]

109. Donato, A.J.; Uberoi, A.; Bailey, D.M.; Wray, D.W.; Richardson, R.S. Exercise-induced brachial artery vasodilation: Effects of antioxidants and exercise training in elderly men. Am. J. Physiol. HearT Circ. Physiol. 2010, 298. [CrossRef]

110. Park, J.B. Reduction of dehydroascorbic acid by homocysteine. Biochim. Biophys. Acta Gen. Subj. 2001, 1525, 173-179. [CrossRef]

111. Frei, B. Natural Antioxidants in Human Health and Disease; Elsevier Inc.: Amsterdam, The Netherlands, 2012; ISBN 9780122669750. 
112. Yun, J.; Mullarky, E.; Lu, C.; Bosch, K.N.; Kavalier, A.; Rivera, K.; Roper, J.; Chio, I.I.C.; Giannopoulou, E.G.; Rago, C.; et al. Vitamin C selectively kills KRAS and BRAF mutant colorectal cancer cells by targeting GAPDH. Science 2015, 350, 1391-1396. [CrossRef]

113. Huber, A.; Thongphasuk, P.; Erben, G.; Lehmann, W.D.; Tuma, S.; Stremmel, W.; Chamulitrat, W. Significantly greater antioxidant anticancer activities of 2,3-dehydrosilybin than silybin. Biochim. Biophys. Acta Gen. Subj. 2008, 1780, 837-847. [CrossRef] [PubMed]

114. Khan, M.K.; Ahmad, K.; Hassan, S.; Imran, M.; Ahmad, N.; Xu, C. Effect of novel technologies on polyphenols during food processing. Innov. Food Sci. Emerg. Technol. 2018, 45, 361-381. [CrossRef]

115. Gliemann, L.; Schmidt, J.F.; Olesen, J.; Biensø, R.S.; Peronard, S.L.; Grandjean, S.U.; Mortensen, S.P.; Nyberg, M.; Bangsbo, J.; Pilegaard, H.; et al. Resveratrol blunts the positive effects of exercise training on cardiovascular health in aged men. J. Physiol. 2013, 591, 5047-5059. [CrossRef] [PubMed]

116. Wani, G.; Milo, G.E.; D'Ambrosio, S.M. Enhanced expression of the 8-oxo-7,8-dihydrodeoxyguanosine triphosphatase gene in human breast tumor cells. Cancer Lett. 1998, 125, 123-130. [CrossRef]

117. Bases, R.; Franklin, W.A.; Moy, T.; Mendez, F. Enhanced excision repair activity in mammalian cells after ionizing radiation. Int. J. Radiat. Biol. 1992, 62, 427-441. [CrossRef] [PubMed] 